\section{mag. Jana \\ Kalin

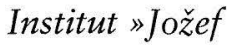 \\ Stefan«, Ljubliana}

\title{
MORALNI RAZVOJ OSEBNOSTI
}

\author{
Vloga izobraževanja pri oblikovanju \\ in spreminjanju stališč
}

\section{I}

lzobraževanje postaja in je vseživljenjski proces, kot osebnostni razvoj sam. V prispevku najprej predstavim različne psihološke teorije in njihove poglede na moralni razvoj, nato pa se omejim na oblikovanje in spreminjanje stališč ter na vlogo izobraževanja v teh dveh procesih, s posebnim poudarkom na pomenu okolja oz. skupine, ki ji posameznik pripada.

Celoten koncept permanentnega izobraževanja vsebuje razumevanje človeka, njegovega značaja, hotenj, želja in smisla življenja. Človek je živ organizem, ki se razvija, spreminja, nastaja. (Lengrand, 1976)

Človek postaja to, kar je, vse svoje življenje. In neprestano hrepeni po sreči in življenju, ki bo zares polno, bogato, smiselno. Koliko mu lahko tudi izobraževanje oz. permanentno izobraževanje pri tem pomaga?

Morda še posebno na področju moralnega razvoja osebnosti, ki vključuje tudi razvoj

Ko je Heath (Psihodiagnostika osebnosti, 1994) opravil raziskavo, v kateri je spraševal strokovnjake in nestrokovnjake, kako si zamišljajo zrelo osebnost, so se preizkušanci najboli strinjali glede naslednih lastnosti:

* realistiéen odnos do življenja

* občutek za prave (?) vrednote

* dobra integriranost

* odprtost za nove izkušnje

s sposobnost za nadalinj razvoj

* prilagodlivost

* tolerantnost

* sposobnost za uravnavanje napetosti vsakdanjega Żvljenja

* toplina in spostovanje drugih

vrednostnega sistema in stališč, ne moremo razvoja omejiti le na obdobje otroštva in mladostništva in ga omejiti s - katero koli že starostno mejo.

Osebnostni razvoj je proces. Je vse življenje trajajoč proces iskanja, odkrivanja, najdevanja, razmišljanja, čustvovanja ... s številnimi obdobji rasti in padcev, bogatenja in težav.

$\mathrm{Na}$ vseh teh področjih ima pomembno vlogo tudi izobraževanje, ki naj pomaga ljudem $\mathrm{k}$ večji kakovosti življenja.

\section{RAZLIČNI POGLEDI NA MORALNI RAZVOI}

Psihoanalitične teorije moralnega razvoja človeka označujejo za konfliktno bitje, ker se neprestano sooča $\mathrm{z}$ nasprotji med lastnimi instinktivnimi potrebami in zahtevami družbe, v kateri živi. Stalno doživlja frustracije, ker ne more zadovoljiti vseh potreb. Otrok mora v času svoje socializacije potlačiti sovražnost do avtoritet, ki vsiljujejo norme in zahteve, zaradi strahu pred izgubo njihove ljubezni in naklonjenosti. Tako usvoji njihova pravila obnašanja in razvije motive po posnemanju njihovega obnašanja. Gre za proces identifikacije s starši. Konfliktnost nastaja zaradi moči superega $\mathrm{v}$ nasprotju $\mathrm{z}$ instinktivnimi potrebami posameznika.

Teorije socialnega učenja, behavioristične teorije zastopajo stališče, da otrok ob rojstvu ni ne pokvarjen niti popolnoma čist, temveč neskončno prilagodljiv (»tabula rasa «). Moralno vedenje so specifična dejanja, ki se jih posameznik nauči na podlagi nagrade in kazni. Za otroka so starši vir pozitivnega in negativnega ojačanja vedenja. Pozitivno ojačanje je pohvala, nasmeh, pozornost, darilo, negativno pa odtegnitev privilegijev, udarec, ignoriranje, izolacija. Veliko vedenja se posameznik nauči z neposrednim opazovanjem in posnemanjem modela, če je njegovo vedenje nagrajeno, če pa je vedenje modela kaznovano, se bo tudi sam tako počutil in se kasneje tudi sam izogibal takemu vedenju. Vendar pa moralnega razvoja ne moremo reducirati le na nekatere procese učenja. 
Teorije samooblikovanja, kognitivistične teorije se sprašujejo, v kakšnem razmerju je moralni razvoj s spoznavnim razvojem otroka. Moralni razvoj je spoznavanje in sprejemanje moralnih norm. Moralno dejanje pa pomeni otrokovo razumsko presojo o pravilnosti ali nepravilnosti nekega dejanja. Spoznavni razvoj sam po sebi še ne zadošča za to, da bi otrokova dejanja resnično pričeli voditi moralni nagibi. Otrok potrebuje tudi raznovrstne socialne izkušnje. Kognitivistične teorije poudarjajo, da je kognitivni razvoj primaren, moralni razvoj pa le izhaja iz njega. Oba potekata v stopnjah, pri čemer je vsaka stopnja otrokovega funkcioniranja nujno rezultat predhodnih stopenj in hkrati priprava na naslednjo stopnjo. Ta razvoj poteka v smeri vse večjega ravnovesja med procesom vklapljanja in prilagajanja novih izkušenj že obstoječim kognitivnim strukturam ter procesi akomodacije - prilagajanja že obstoječih miselnih struktur zahtevam okolja. Gibalo otrokovega razvoja je neprestano vzdrževanje ravnotežja med obstoječimi kognitivnimi strukturami in novimi informacijami iz okolja. Moralni razvoj je aktiven proces, ki je rezultat razvoja kognitivnih struktur v sodelovanju s socialnimi izkušnjami.

$\mathrm{V}$ bistvu gre za razvoj od absolutnosti $\mathrm{k}$ relativnosti moralne perspektive:

- Absolutnost moralne perspektive je značilna za heteronomno moralo. Otrok v tem obdobju razume družbena pravila kot toga, absolutna in nespremenljiva. Zahtevam odraslih se podreja zaradi občutka nesposobnosti presojanja in močnega emocionalnega doživljanja odraslih avtoritet. Otrok se podreja pravilom zato, da bi se izognil kazni. Razvije se močan občutek, da se mora podrejati pravilom odraslih, vendar ne zato, ker bi poznal vsebino pravil, ampak zaradi strahu pred kaznijo.

- Relativnost moralne perspektive je značilna za avtonomno moralo. Prehod v to stopnjo pomeni opuščanje egocentrizma, ker otrok dozoreva in dobiva že izkušnje iz okolja. Pravila na tej stopnji niso več nekaj, kar otrok dobi od zunaj, pač pa jih pojmuje kot nastale iz recipročnih družbenih dogovorov. Njegove sodbe o pravilnosti ali nepravilnosti dejanj $\mathrm{v}$ pretežni meri determinira namen.

\section{KOHLBERGOVO POIMOVANJE MORALNEGA RAZVOJA}

Ameriški psiholog Lawrence Kohlberg je moralni razvoj opredelil kot razvoj razumevanja družbenih norm, pravil in zakonov, vzajemnosti v medosebnih odnosih in temeljnih moralnih pojmov, ki naj bi obstajali prisotni v vsaki družbi. Na podlagi longitudinalnih empiričnih podatkov je dokazal, da moralni razvoj poteka $v$ šestih stopnjah, katerih vrstni red pojavljanja je kulturno invarianten in univerzalen. Vsaka naslednja stopnja predstavlja logično diferenciacijo in integracijo predhodne stopnje. Stopnje moralnega razvoja je določal iz prostih odgovorov na 10 hipotetičnih moralnih

Kohlberg je moralni
razvoj osebnosti
razvrstil vzdolž šestih
stopenj.
dilem. Pri tem ga ni toliko zanimala vsebina odgovorov kot način njihovega utemeljevanja, ki predstavlja kakovost moralne sodbe.

Stopnje moralnega razvoja $\mathrm{v}$ njegovem sistemu so:

1. stopnja: usmeritev $\mathrm{k}$ poslušnosti in strahu pred kaznovanjem

Sociomoralna perspektiva posameznika je egocentrična. $\mathrm{V}$ moralnem presojanju prevladuje strah pred kaznovanjem in nagnjenost $\mathrm{k}$ poslušnosti. Posameznik ustreže po položaju močnejšim in vplivnejšim, ker se boji neugodnih posledic ali kaznovanja. Kot dobro opredeljuje tisto, kar je skladno $\mathrm{z}$ zahtevami avtoritet, in ne sprejema možnosti, da ima lahko vsak posameznik lasten pogled na to, kaj je pravilno in kaj napačno. Pri presojanju moralnega dejanja pripisuje bistveni pomen nepomembni fizični obliki dejanja (npr. velikost laži) in njegovim neposredno opazljivim posledicam (npr. količina fizične škode).

\section{2. stopnja: instrumentalno relativistična} usmeritev

Sociomoralna perspektiva je konkretna in individualistična. Posameznik spozna, da ima vsak človek lastne interese in potrebe, ki so velikokrat $\mathrm{v}$ spornem razmerju $\mathrm{z}$ interesi drugih ljudi. Potrebe in želje drugih pa pretežno upošteva le takrat, ko se mu to zdi potrebno in uporabno. Prav tako pri presojanju dejanj delno upošteva motive, ki so za njimi, in olajševalne okoliščine. V moralni sodbi že zanemar- 


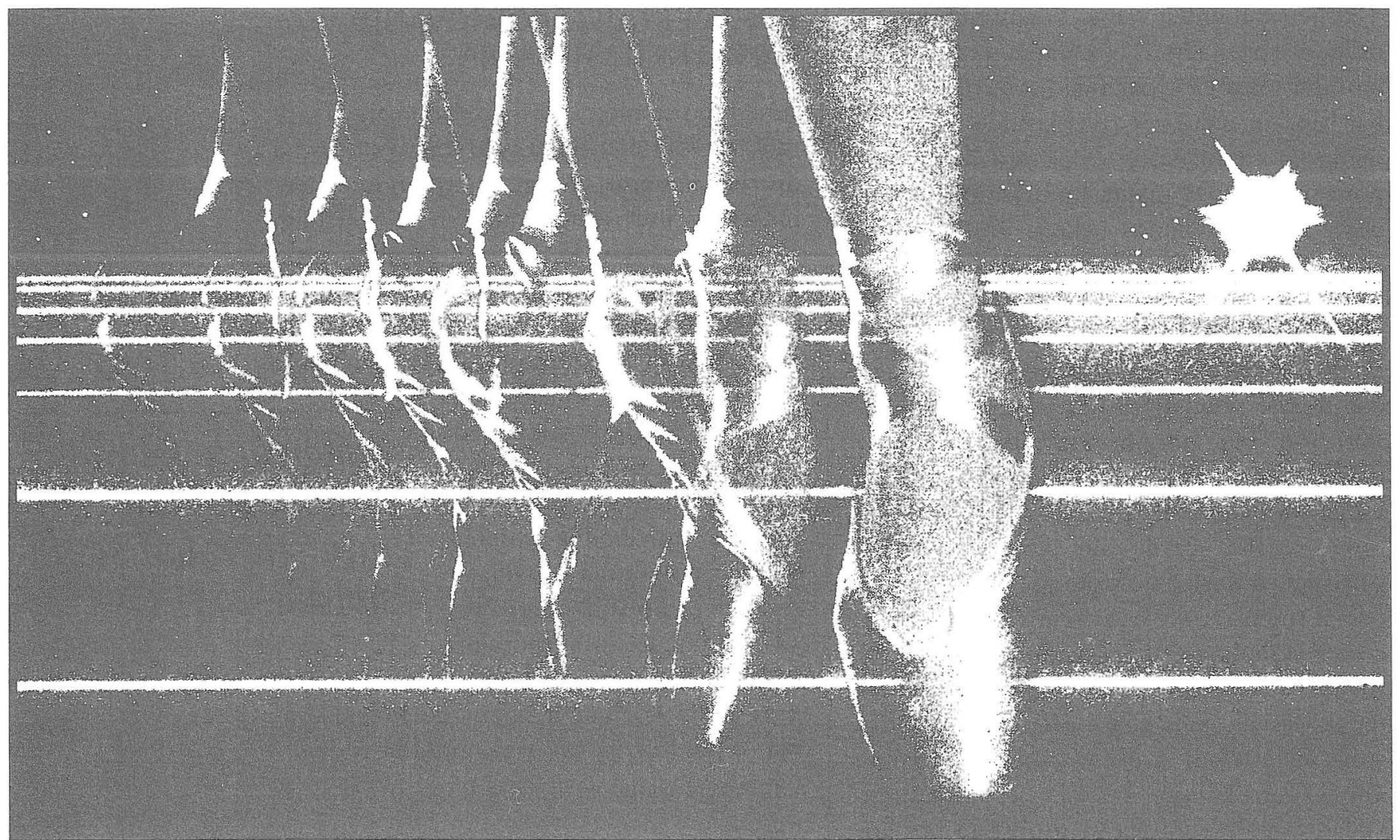

ja zunanjo obliko in fizične posledice dejanja. Pravičnost doživlja kot sistem vzajemne zamenjave po načelu: »Ti meni, jaz tebi.«

3. stopnja: usmeritev $\mathrm{k}$ medsebojnemu ujemanju

$\mathrm{Na}$ tej stopnji so posamezniku bistveno pomembnejši medosebni odnosi. Soglašanje $z$ drugimi, spoštovanje občutij in pričakovanj drugih premaga individualne interese. Kriterij za presojanje pravilnosti in nepravilnosti dejanj je posamezniku družbeno odobravanje in neodobravanje. Ljudem skuša ustreči, upoštevati njihovo mišljenje, jim pomagati. Za moralno osebo šteje tisto, ki ima moralne vrline (tiste, ki jih njegova ožja družbena skupina šteje za take) in ki usklajuje svoje potrebe $s$ potrebami drugih. Pri moralnem presojanju upošteva tudi olajševalne okoliščine (npr. dobre namene). Dejanje, katerega posledice so slabe, je opravičljivo, če so za njim družbeno sprejemljivi in altruistični motivi.

\section{4. stopnja: usmeritev $\mathrm{k}$ zakonitosti in redu}

Posameznik sprejema pravila in stališča, ki jih "zastopa « družbeni sistem. Spoštuje red, zakone, sprejete družbene norme in kode vedenja. Meni, da se je vsak posameznik dolžan ravnati skladno z njimi. Moralno je zanj tisto, kar družba šteje in sprejema kot pravilno in dobro. Posamični interesi, sočustvovanje $\mathrm{z}$ drugimi, spoštovanje njihovih potreb so za posameznika sprejemljivi le, če se skladajo $\mathrm{z}$ obstoječimi družbenimi kodi. Sicer jih zavrne. Pravičnost ni več odvisna od posameznikove ocene situacije, temveč od vnaprej uravnanih pravil in odnosov v družbi, ki jih spoštuje tudi, če se mu zdijo nelogični. Poudarjeno izraža potrebo po družbenem redu in upoštevanju predpisov, pri čemer se ne sprašuje o globljem smislu zakonov in dolžnosti, temveč jih sprejema kot avtoritativne smernice, ki veljajo enako za vse ljudi, ne glede na okoliščine. Družbeno pravilo po njegovem mnenju vedno koristi in zaščiti druge, kršenje teh pravil pa jih vedno na kakršen koli način oškoduje.

5. stopnja: usmeritev k vzajemnemu družbenemu soglasju

Posameznik prepozna poljubno prvino moralnih pravil ali družbenih pričakovanj $\mathrm{v}$ medsebojnem dogovarjanju in soglasju. Dolžnost opredeljuje kot dogovor med ljudmi, ki se ga je potrebno držati zaradi tega, ker je to najbolje za večino ljudi. Okoliščine delno opravičujejo dejanja, ki od družbeno spreje- 
tih norm odstopajo, vendar ne vodijo do odpravljanja moralnih kategorij. Posameznik, ki je na 5. stopnji, sprejema dejstvo, da je družbeni sistem s svojimi normami neizogibno potreben, čeprav vseh njegovih norm ne odobrava. Namesto da bi jih kršil, meni, da bi jih bilo potrebno spremeniti in uzakoniti z dogovarjanjem med ljudmi. V okviru obstoječih družbenih norm zahteva še dovolj prostora za lastno svobodo odločanja in druge državljanske pravice. Družbena pravila, norme in zakoni se morajo po demokratični poti spreminjati in izgrajevati, kajti vsi obstoječi kodeksi niso vedno pravi za večino pripadnikov družbe. Posameznik ocenjuje obstoječi družbeni kodeks s perspektive pravičnosti, enakosti in svobode. Kohlberg jo zato imenuje perspektivo ustvarjanja zakonov, medtem ko je za četrto stopnjo značilno spoštovanje zakona.

6. stopnja: usmeritev $\mathrm{k}$ univerzalnemu etičnemu načelu

Izraža razumno moralno perspektivo, ki spoštuje določena splošna moralna načela. Ta načela so univerzalna, $v$ tolmačenju pa precej raznolika (npr. človekove pravice, življenje, smisel življenja). Posameznik si jih postopoma izoblikuje sam, $\mathrm{z}$ njimi pa uravnava svoje življenje, ne da bi si pri tem pomagal s konkretnimi predpisi in prepovedmi. Če meni, da je obstoječi družbeni zakon v nasprotju s takim načelom, svoje odločitve oblikuje na podlagi osebnega načela. Ko ravna drugače, doživlja občutke krivde in samoobtoževanja. Za posameznika je neko dejanje moralno pravilno, če je v skladu s samosprejetim moralnim načelom. Odstopanja od zakonitih pravil opravičuje, ko izbira med odstopanjem od teh pravil in odstopanjem od lastnega načela.

\section{NIVOII MORALNE USMERJENOSTI}

Kohlberg je po dve stopnji združil in tako je dobil tri nivoje moralne usmerjenosti. $\mathrm{Za}$ predkonvencionalno sta značilni zunanja motivacija in zunanji nadzor dejanj. Motivacija za presojo in vedenje temelji na strahu pred kaznijo (1. stopnja) oz. na želji po nagradi pridobivanju koristi (2. stopnja). Skladno s tem se norme posameznika prilagajajo tistim, ki jih od njega zahtevajo avtoritete.

Motivacija za presojanje in vedenje na ravni konvencionalne usmerjenosti je že notranja, tj. predvidevanje družbenega odobravanja ( 3 . stopnja) poštenosti, krivde ob kršenju institucionaliziranih dolžnosti in iz tega izhajajočega oškodovanja drugih (4. stopnja). Nadzor dejanj pa ostaja zunanji, tj. pravila vedenja postavlja družba.

Pri postkonvencionalni usmerjenosti sta tako motivacija kot nadzor dejanj notranja. Motivacija na 5. stopnji izhaja iz potrebe po ohranitvi samospoštovanja, doslednosti in razumnosti, na 6. stopnji pa iz potrebe po vzdrževanju lastnih samoizbranih vrednot in načel. Pri tem norme presojanja in vedenja izhajajo iz posameznika samega, odločitve temeljijo na lastni presoji.

\section{RAZVOI MORALNEGA PRESOJANIA}

Kohlberg je svoj način ocenjevanja moralnih dilem večkrat popravljal. Zadnjih deset let se tako vedno bolj uveljavlja preizkus Jamesa Resta, ki ga sestavlja šest Kohlbergovih moralnih dilem.

Pri določanju stopnje moralnega razvoja nas ne zanima toliko vsebina odgovora, kakor način sklepanja o moralni dile$\mathrm{mi}$ in način odločanja o tem, kateri odgovor je za posameznika pravi. Ljudje namreč lahko enako odgovarjajo na

Za moralni razvoj je pomemben predusem način sklepanja 0 moralni dilemi. moralne dileme, vendar v ozadju njihovih presoj stoji drugačna vrednotna logika.

Restov model vsebuje štiri sestavine, ki predstavljajo štiri temeljne procese, nujno potrebne za pojav moralnega vedenja. Moralni razvoj po njegovem mnenju ni rezultat enega in enotnega procesa, čeprav eden lahko vpliva na druge. Procesi sicer delujejo interaktivno, vendar ni nujno, da ima posameznik $\mathrm{z}$ visoko razvito eno sestavino tudi ustrezno razvite preostale sestavine. Interakcije med njimi so zapletene in se ne pojavljajo vedno po spodaj opisanem zaporedju. Vsak proces vsebuje različne načine spoznavno čustvenih povezav, ki se povezujejo $\mathrm{z}$ moralnim vedenjem, ne vsebujejo pa osebnostnih potez niti vrednot, ki bi tvorile moralno osebo. Obravnavamo jih lahko le kot temeljne enote za analizo in spremljanje posameznih oblik moralnega vedenja v posamičnih situacijah. 
1. sestavina: sposobnost razlaganja moralne situacije

Vsebuje prepoznavo situacije, posameznikova prva čustva $v$ okviru te situacije, oblikovanje možnih načinov delovanja, predvidevanje možnih posledic, možnih moralnih norm, ki bi bile uporabne. Poleg spoznavnih sposobnosti zahteva ta sestavina tudi določeno stopnjo empatije. Prepoznavanje in razlaga situacije sta odvisni tudi od delovanja obrambe jaza in prvega vtisa, ki v posamezniku vzbudi močna čustva. Tako čustveno vzburjenje se pojavlja neodvisno od zavednega nadzora in ostane $\mathrm{v}$ vsakem primeru del situacije, ki jo posameznik tolmači.

2. sestavina: sposobnost presojanja pravilnih načinov delovanja

Vsebuje zbiranje pravilnih, pravičnih, dobrih odločitev. Gre za oblikovanje moralnih sodb

Moč za izvedbo

moralnega dejanja črpamo iz našega jaza. oz. proces presojanja, pojasnjevanja in dokazovanja pravilnosti dejanj. Z razvojem spoznavnih sposobnosti in kopičenjem socialnih izkušenj postaja tudi moralno presojanje vse bolj zapleteno in ustrezno danemu družbeno moralnemu prostoru. Temelje moralnemu presojanju predstavljajo nivoji razvoja pojmov družbenega sodelovanja, pravičnosti, enakosti in spremljajoča čustva moralne odgovornosti, ki jih vključuje razumevanje družbene organizacije. Na moralno presojanje pa lahko vpliva tudi pripadnost določenemu sistemu prepričanj in ideologij, močan stres in patološka fiziološka stanja.

3. sestavina: sposobnost določanja prednosti izbranim vrednotam

Med posameznimi delovanji, ki jih je posameznik ovrednotil kot pravilna, izbira, katero izmed njih je pravilnejše, boljše, katero vsebuje vrednote, ki so v dani situaciji pomembnejše. Izbira tako med moralnimi kot tudi osebnimi vrednotami. Moralni ideali lahko v dani situaciji izgubijo prednost na račun drugih vrednot, ki so za posameznika ali skupino pomembnejše. Tudi zaradi tega prihaja do razhajanj med besedno oceno moralnih vrednot in posameznikovim vedenjem. Ponavadi vsaj dve ali celo več različnih vrednot določa posameznikovo vedenje $\mathrm{v}$ dani situaciji in času. Posameznik v tem tretjem procesu na zapleten način izbere tisti način delovanja, za katerega meni, da je $\mathrm{v}$ danem okolju in trenutku najboljši. Ta odločitev pa oblikuje namero za moralno delovanje.

\section{4. sestavina: sposobnost izvedbe moralnega dejanja}

Predstavlja sledenje nameri moralne odločitve oz. pripravljenost za uresničevanje vedenja, ki ga je posameznik izbral kot moralno najbolj pravilnega. Eden izmed najpomembnejših dejavnikov sposobnosti izvedbe je moč jaza. Posameznik s šibkim jazom sicer lahko ima veliko moč prepričanj, vendar pa le-teh ni zares pripravljen uresničevati v konkretni situaciji. Dejansko izvedbo dejanja določajo tudi spoznavno preoblikovanje ciljnega objekta (npr. če je posameznik soočen s ciljem, dlje časa vztraja $\mathrm{v}$ akciji), pozitivno čustveno stanje in pričakovanje učinkovitosti dejanja (vpliva na to, ali se bo dejavnost sploh sprožila, koliko truda bo vloženega, koliko časa bo posameznik pripravljen premagovati ovire); na samo vztrajanje v delovanju pa lahko vplivajo spremembe v posameznikovi misli med izvajanjem moralnega dejanja.

\section{OBLIKOVANJE IN SPREMINJANJE STALIŠČ}

Najprej je treba pojasniti, kaj so stališča. Psihologi jih opredeljujejo kot trajna miselna, vrednostna, čustvena in akcijska naravnanja v odnosu do različnih objektov (predmetov, bitij, oseb, dogodkov in pojavov). Stališča vsebujejo več komponent: spoznavno ali ko-

Do pomembnih dogodkov, pojavov, predmetov in oseb nimamo povsem nevtralnega odnosa: ocenjujemo jih, vrednotimo, zavzemamo se zanje ali pa jih odklanjamo. Ljudje se razlikujemo po svojem odnosu do bližnjih oseb, do zgodovinskih osebnosti, do političnih voditeljev, pa tudi do predmetov, živali, dogodkov in pojavov (do svobode, vojne, naroda, gospodarskih vprašanj, umetnosti, vere ...). Ni pomembnega dogodka, stvari ali osebe, do katerih ne bi zavzeli takšnega ali drugačnega stališča. 
gnitivno komponento, ki zajema miselna prepričanja in vrednotenja $\mathrm{v}$ zvezi $\mathrm{z}$ objektom, čustveno komponento, ki zajema čustveni odnos do objekta, in akcijsko komponento, ki zajema pripravljenost, da ravnamo ustrezno. (Musek, 1993b)

Socialni psihologi, ki so definirali pojem stališča, so želeli s tem oblikovati teoretski koncept, ki naj omogoči povezovanje notranjih (duševnih) in zunanjih (fizičnih, socialnih) vidikov obnašanja ljudi. Po teh predpostavkah stabilnost stališč pomembno vpliva na stabilnost obnašanja, sprememba stališč pa nujno vodi do modifikacije obnašanja.

Pojem stališč igra osrednjo vlogo pri socialno-psihološkem modelu razlage in napovedovanja človeškega obnašanja. Stališča usmerjajo naše početje v svetu in obratno, spremembe $v$ socialnem svetu se najprej pokažejo v naših stališčih, ki nato vplivajo na spreminjanje naših dejanj ali vedenjskih oblik. Ker so stališča tesno povezana z obnašanjem, imajo ključni pomen za izoblikovanje predstav o nas samih, naše motivacijske strukture ..., torej socialne konstrukcije subjekta, pa tudi za izoblikovanje predstav o drugih ljudeh in raznih sestavinah družbene stvarnosti.

Stališča in njihova dinamika so postala eden najbolj raziskovanih pojavov v socialni psihologiji, zlasti v ameriški socialni psihologiji, kjer se je tudi najprej izoblikoval psihološki pojem stališča. Pojem stališča omogoča zajeti tisto, kar je cilj vsakega znanstvenika - predvidevanje. Pojem stališča je pomemben tudi zato, ker zajema in prikazuje kompleksno soodvisnost človekove duševnosti in njegovega socialnega obnašanja. Nobena druga osebnostna lastnost ni toliko pod vplivom socialnih dejavnikov in nobena druga lastnost ne vpliva tako močno na dogajanja med ljudmi kot prav struktura stališč posameznika. Prav razlike v stališčih so vzrok konfliktov, sporov, vojn, sumničenj ... med ljudmi. (Zvonarević, 1978)

Rosenberg in Hovland definirata stališča kot predispozicije posameznikov za pozitiven ali negativen odgovor na določeno dogajanje ali situacijo v socialnem svetu. Krech, Crutchfield in Ballachey pravijo, da so stališča trajni sistemi pozitivnega ali negativnega ocenjevanja, občutenja in aktivnosti v odnosu do različnih socialnih situacij in objektov. (NastranUle, 1994)
Različne definicije stališč poudarjajo nekatere skupne značilnosti pojma stališč:

1. Dispozicijski karakter stališča: stališča so trajna duševna pripravljenost za določen način reagiranja.

2. Pridobljenost stališč: stališča pridobivamo v teku življenja, v procesih socializacije.

3. Delovanje na obnašanje: stališča imajo direktivni in dinamični vpliv na obnašanje in vplivajo na doslednost oz. konsistentnost človekovega obnašanja.

4. Sestavljenost oz. kompleksnost stališča: stališča so integracija treh osnovnih duševnih funkcij: kognitivne, emotivne in dinamične in zato vedno vsebujejo te komponente. ( $\mathrm{Na}$ stran-Ule, 1994)

- Kognitivna komponenta stališč so znanja, vedenja, izkušnje, informacije, tudi vrednostne sodbe in argumenti $v$ zvezi $\mathrm{z}$ objektom, dogodkom, osebo ali situacijo, o kateri oblikujemo stališče. Vsako stališče temelji na znanju in poznavanju situacij in stvari, do katerih imamo stališče. Najosnovnejša oblika kognitivnega elementa stališča so kategorije, s katerimi razvrščamo objekte v razrede. Če je objekt stališč oseba, je kognitivna komponenta pogosto kak stereotip. Stališča, ki so zasnovana na nepreverjenih dejstvih, govoricah, imenujemo predsodki.

- Emotivna oz. evalvativna komponenta stališč so pozitivna ali negativna občutja in ocenjevanja objektov stališč. Določene osebe, socialne situacije, dogodki lahko vzbujajo simpatijo, privlačnost, obžalovanje, strah, jezo, zaničevanje ... Kognitivna in emotivna komponenta sta običajno usklajeni med seboj. Če pride do razlik med njima, to skoraj nujno vodi do spremembe stališča bodisi $\mathrm{z}$ dodajanjem novih informacij bodisi z apelom na naša čustva.

- Konativna (aktivnostna, dinamična) komponenta je težnja ali dispozicija posameznika, da deluje na določen način glede na objekt stališč, ko npr. podpre tiste objekte ali situacije, do katerih ima pozitivna stališča, oziroma prepreči tiste pojave ali situacije, do katerih ima negativna stališča. Poudarek je torej na pripravljenosti za delovanje, ne pa na dejavnosti sami.

Med kognitivno, emotivno in konativno dimenzijo obstaja tesna povezanost in preplete- 
nost. Stališča so zelo povezana s čustvi, motivi, potrebami. Ne moremo jih neposredno zaznati, opazovati ali meriti, nanje lahko sklepamo iz drugih empiričnih podatkov, pomagajo pa nam razložiti obnašanje in spremembe obnašanja posameznikov ali skupin.

\section{Stališče v odnosu do prepričanja, mnenja in vrednote}

Stališče pogosto zamenjujemo $\mathrm{s}$ prepričanjem. Kot imamo stališče do nečesa, imamo tudi prepričanje o nečem. Bistvena razlika med prepričanjem in stališčem je $\mathrm{v}$ tem, da je prepričanje zasnovano samo na intelektualni komponenti, medtem ko je stališče zasnovano na intelektualni, emocionalni in aktivnostni komponenti. Pri prepričanju se sklicujemo na dejstva, argumente.

Mnenja (»opinion «) so bolj specifična od stališč, bolj nestabilna in lažje spremenljiva. Mnenja pomenijo konkretizacijo, manifestacijo stališč v konkretnih situacijah. Stališča pa pomenijo integracijo mnenj, kakor pravi Eysenck: več specifičnih mnenj o objektu, situaciji privede do oblikovanja stališča o tem objektu, situaciji.

$S$ pojmom stališče pogosto zamenjujemo tudi pojem vrednote. Vrednote so ideje ali situacije, ki pomenijo nekaj pozitivnega, zaželenega, nekaj, za kar si prizadevamo, za kar se je treba zavzemati. Vrednote so pojmovanja o ciljih in pojavih, ki jih visoko cenimo, za katere se $\mathrm{v}$ življenju zavzemamo in $\mathrm{k}$ čemur težimo. Vrednote so splošnejše od stališč in so lahko izvor mnogih stališč.

\section{FUNKCIJA STALIŠČ}

Stališča vplivajo na mentalno pripravljenost za določen način reagiranja in zato vplivajo

Hitreje si zaupamo stvari, ko so $v$ skladu $z$ našimi stališči.
Psiholog D. Katz v svoji teoriji o funkcionalnem karakterju stališč govori predvsem o naslednjih funkcijah stališč (Nastran-Ule, 1994):

- Obramba jaza: nekatera stališča nam služijo za to, da nas branijo pred trdo resničnostjo življenja in pred negativnimi spoznanji o nas samih. Služijo kot obrambni mehanizmi, ki nas branijo pred notranjimi bolečinami. Tipičen mehanizem je projekcija: drugim pripisujemo tiste svoje lastnosti, ki jih pri sebi ne sprejmemo, in na ta način ločimo sebe od teh lastnosti.

- Vrednotno-ekspresivna funkcija: ljudje imamo potrebo po izražanju tistih stališč, ki nam omogočajo posredovanje osrednjih vrednotnih predstav ali pomembnih komponent njihovih predstav o sebi. Takšna stališča krepijo občutek samorealizacije in samoizražanja.

- Instrumentalna oz. prilagoditvena funkcija: stališča nam lahko pomagajo doseči zaželene cilje, nagrade ali pa se izogniti nezaželenim dogodkom, kaznim.

- Kognitivna funkcija: stališča nam lahko pomagajo organizirati in strukturirati kaotičen svet. Omogočajo nam klasificirati nove informacije in izkušnje. $S$ tem nam pomagajo poenostaviti in bolje razumeti kompleksni svet, $\mathrm{v}$ katerem živimo.

\section{STRUKTURA STALIŠČ}

Raziskave stališč kažejo, da ljudje težimo $\mathrm{k}$ organiziranju naših stališč v celoto tako, da so stališča medsebojno usklajena. Socialni psihologi so razvili več teorij, ki pojasnjujejo nastanek in ohranjanje konsistentnosti stališč. Tem teorijam je skupno spoznanje, da ljudje prilagajamo stališča drugim stališčem tako, da se ohrani konsistentnost celote. Osnovne teorije, ki pojasnjujejo konsistentnost stališč, so: Heiderjeva teorija ravnotežja, Sherifova teorija polarizacije, Abelsonova in Rosenbergova teorija afektivno-kognitivne konsistence, Osgood-Tannenbaumova teorija kongruence in Festingerjeva teorija kognitivne disonance.

Fritz Heider je postavil tezo, da skušamo ljudje nenehno vzpostavljati in ohranjati stanje ravnotežja med stališči. Stališča, ki se nam zdijo v neskladju z drugimi stališči, povzročajo neugoden občutek kognitivnega neravnotežja. Zato ljudje težimo k odpravljanju nerav- 
notežja, torej spreminjamo mrežo stališč tako, da se ponovno vzpostavi ravnotežje med njimi.

Abelsen in Rosenberg sta povsem kognitivistično Heiderjevo teorijo ravnotežja dopolnila $\mathrm{z}$ afektivno komponento (ne)konsistence in tako razvila teorijo afektivno-kognitivne konsistence. Razvila sta zapleten sistem šestih pravil, ki določajo, kdaj bo nekdo občutil nekonsistentnost med svojimi stališči. Nekonsistentnost stališč lahko odpravimo z redefinicijo stališč, z redefinicijo posameznih afektivnih povezav ali pa $z$ vključitvijo celotnega nekonsistentnega sistema stališč v kak bolj obsežen kognitivni sistem, v katerem ni več nekonsistentnosti. Osnovno pravilo pri teh operacijah pa je, da posameznik ravna tako, da pri tem porabi čim manj duševnega napora.

$\mathrm{Na}$ vzpostavljanje konsistentnosti $\mathrm{v}$ stališčih vpliva tudi to, koliko je neko stališče v mreži stališč dostopno ali »blizu" posamezniku. Sherif in Hovland sta ugotovila, da lahko vsako stališče razvrstimo na nekem kontinuumu "bližine« oz. "oddaljenosti « za posameznika. Tista stališča, ki se nam zdijo bližja oz. so tudi bolj dostopna za nas, zaznavamo za še bližja, kot so glede na svojo objektivno vsebino (asimilacija stališč), medtem ko stališča, ki so za nas bolj oddaljena, manj dostopna, ocenjujemo za še bolj oddaljena, kot so glede na svojo objektivno vsebino (kontrastiranje stališč). Ta pojav imenujemo polarizacija stališč.

Po Sherifu in Hovlandu predstavljajo naša stališča neke vrste "sidra ", glede na katera ocenjujemo vse druge možne odnose med lastnimi stališči in stališči, ki od naših odstopajo. Ugotovila sta, da je polarizacija stališč večja pri posameznikih, ki so bolj vpleteni v situacijo, ki jo ocenjujejo (ego-involvement).

Osgood in Tannenbaum sta na osnovi spoznanj o neenaki teži različnih nekonsistentnosti med stališči razvila teorijo kongruence. $\mathrm{Na}$ splošno velja, da ljudje občutimo nekonsistentnost stališč šele tedaj, ko ta stališča zares povežemo med seboj. Vpeljala sta skalo $z$ več enotami v razponu od maksimalno negativne vrednosti prek nevtralne vrednosti $(0)$ do ustrezne maksimalno pozitivne vrednosti. Ljudje imamo do različnih objektov svojih stališč različno močne pozitivne ali negativne vrednosti, ali pa imamo do nečesa nevtralen odnos. V procesu odpravljanja nekonsisten- tnosti moramo najprej urediti razmerja med stališči, ki imajo največjo (negativno ali pozitivno) vrednost. Res pa je, da najteže spreminjamo stališča, ki imajo ekstremne vrednosti.

\section{Teorija kognitivne disonance}

Najbolj znana in obdelana teorija konsistentnosti je Festingerjeva teorija kognitivne disonance. Po Festingerju gre v procesu odpravljanja nekonsistentnih stališč za vzpostavljanje konsonance oz. skladnosti stališč. Njeno nasprotje imenujemo disonanca. Pri disonanci gre za navzkrižje med stališči, namreč eno stališče nasprotuje drugemu oz. temu, kar iz njega izhaja. Pomembno se je zavedati, da gre za občutek disonance in ne nujno za stvarno disonanco. Ljudje namreč reagiramo na tisto disonanco, ki jo čutimo in kakor jo čutimo, ta

Človek ni nikoli v popolni konsistenci glede svojih prepričanj, neprestano mora reducirati to ali ono občuteno disonanco, hkrati pa se velikega števila disonanc niti ne zaveda. Kakšno strategijo za redukeijo disonance posameznik izbere, pa je odvisno od osebnostnih, kulturnih in socialnih dejavnikov.

pa je lahko enaka dejanski neskladnosti stališč ali pa ne. Odpravi disonance pravi Festinger redukcija disonance. Pri pojmu disonance je Festinger upošteval tako neskladje med komponentami stališč kot neskladje med stališči in obnašanjem posameznika. Raziskoval je tudi neujemanja med stališči in vedenjem neke osebe. Tudi to je imel za disonanco, ki zahteva svojo odpravo.

Brehmova in Cohenova teorija vezanosti (commitment) in prostovoljnosti (volition) je pomembno dopolnilo Festingerjeve teorije.

Vezanost pomeni, da smo s sprejemanjem neke odločitve, z nekim dejanjem ali z ne-dejanjem tako ali drugače aktivno vpleteni in soodgovorni za dogajanje okoli nas. Ljudje smo torej vezani na odločitve, dejanja in na njihove posledice. Zato težimo $\mathrm{k}$ reduciranju vseh disonantnih elementov, ki izvirajo iz nepovratnosti naše vpletenosti v dogodke.

Prostovoljnost se nanaša na občutek posameznika o tem, da ima največjo možno svobodo izbire. Le ljudje, ki imajo tak občutek, lahko občutijo disonanco med svojimi stališči (namerami, cilji) in rezultati svojih odločitev (dejanj). Če so namreč prisiljeni v neko početje, potem že zametke disonance zelo hitro od- 
pravijo s tem, da se sklicujejo na zunanjo prisilo oz. na lastno neodgovornost za dejanja.

Aronson in njegovi sodelavci so razvili teorijo, kjer povežejo koncept sebe in disonance. Disonanca ni preprosto med dvema ali več stališči, temveč je predvsem med pozitivnim odnosom posameznika do sebe in drugimi ugotovitvami o sebi. Disonanca postaja toliko bolj nevzdržna, kolikor pomembnejša za posameznika in za njegovo samopodobo so stališča v disonanci. Kolikor večja je disonanca, toliko večja je motivacija posameznika za zmanjševanje disonance.

Nekateri drugi avtorji pa pravijo, da pri disonancah ne gre toliko za notranje kognitivno stanje in reakcije nanj, temveč za željo, da se $\mathrm{v}$ odnosih z drugimi ljudmi vedemo konsistentno. Za začetek redukcije disonance stališč je torej pomembnejše, ali posameznik verjame, da tudi drugi ljudje vedo za njegovo disonanco. Le $\mathrm{v}$ tem primeru bo posameznik sklenil reducirati disonanco. Če nekdo izvaja dejanje, ki ni v skladu s sprejetimi normami, pa ga npr. nihče ne vidi, ga bo disonanca med ravnanjem in njegovimi moralnimi stališči le malo motila. Do močnega občutka disonance pa pride, če gre za dejanje, ki je na očeh javnosti in so njegove posledice zelo pomembne za ljudi, a niso v skladu z normami skupnosti, ki jih sprejema tudi delujoči posameznik.

Te ugotovitve so pripeljale do roba vse tiste teorije, ki so zgolj kognitivno naravnane. Pokazale so, da ne moremo enostavno odstraniti družbenega elementa $v »$ kognitivni strukturi stališč «.

V nekaterih eksperimentih so ugotavljali, da so poskusne osebe z močnimi stališč za nekaj ali proti nečemu znatno hitreje pozitivno ali negativno reagirale na izjave, $k i$ so se skladale $\mathrm{z}$ njihovimi stališči, ali nasprotovale, kot pa na izjave, ki so bile nevtralne glede njihovih stališčc. Drugi poskusi so pokazali, da si poskusne osebe najhitreje zapomnijo tiste informacije, ki podpirajo njihova stališča, nato informacije, ki jim nasprotujejo, in najbolj počasi informacije, ki so nevtralne glede na stališča.

Ljudje torej ne reagiramo neposredno na neravnotežje v kognitivni mreži stališč, pač pa na socialni kontekst, $\mathrm{v}$ katerega postavljamo sebe in svoje obnašanje, kadar ravnamo $\mathrm{v}$ skladu ali v nasprotju s svojimi stališči.

Pomen kognitivne strukture stališč in socialnega konteksta stališč moramo razumeti $\mathrm{v}$ medsebojni povezanosti.
Po Juddu in Kuliku vodijo stališča predelavo relevantnih informacij tako, da polarizirajo informacije na tiste, ki so v skladu s stališčem, in one, ki mu nasprotujejo. Polarizacija informacij olajša shranjevanje informacij v spomi$\mathrm{nu}$ in ponovni priziv informacij. Omogoča nam hitrejše reagiranje na sprejete nove podatke.

Ross pa pravi, da je bolj upravičeno govoriti o stališčih kot pomožnih dražljajih, ki privedejo do poudarjanja tistih oblik vedenja, ki se skladajo s stališči, ali celo do rekonstrukcije preteklega vedenja v luči sprejetih stališč.

\section{OBLIKOVANJE IN SPREMINIANIE STALIŠČ}

Za oblikovanje stališč so najpomembuiejši tile faktorji:

- skupinska pripadnost (vpliv primarnih in referenčnih skupin),

- informacije in znanje (pomen množičnih komunikacijskih sredstev kot izvorov informacij),

- osebnostne lastnosti in značilnosti (izkušnje, trenutne potrebe, motivacija posameznika).

Stališča so relativno stabilni kompleksi kognitivnih, emotivnih, motivacijskih, vedenjskih dispozicij. Zato je njihova sprememba praviloma povezana s spremembo $\mathrm{v}$ dejanskem obnašanju posameznika ali s spremenjenimi pričakovanji o njegovem obnašanju.

Stališča se lahko spreminjajo v:

- intenziteti: od bolj k manj ekstremnim,

- v smeri: od pozitivnih v negativna.

Spreminjanje stališč je odvisno tudi od značilnosti stališč: od ekstremnosti, kompleksnosti, usklajenosti. Bolj ekstremna stališča se težje spreminjajo. Stališče, ki je pri posamezniku povezano $\mathrm{z}$ večjim številom drugih stališč in usklajeno z njimi, je tudi bolj odporno proti spremembam. Poskus spremembe takega stališča lahko izzove učinek bumeranga: lahko torej pride do obratnega učinka, do povečanja intenzivnosti stališča namesto do spremembe.

Pomemben dejavnik konstantnosti in spreminjanja stališč je stabilnost in spreminjanje socialnega sistema, okolja in ideologije. Poleg stabilnega socialnega okolja so najpomem- 
bnejši izvor stabilnosti stališč osebnostne lastnosti in značilnosti posameznika, npr. izkušnje, na osnovi katerih je posameznik oblikoval stališče. Trdnost stališča je odvisna tudi od tega, koliko neko stališče potrjuje predstavo o sebi pri posamezniku. Če je stališče pomembno pri oblikovanju in ohranjanju centralnih lastnosti podobe o sebi, bo seveda posameznik tako stališče želel obdržati.

\section{Vpliv skupinske pripadnosti na oblikovanje stališč}

Skupine, ki jim posameznik pripada, imajo pomembno vlogo pri oblikovanju stališč. Svoj vpliv uveljavljajo tako, da:

- poudarjajo skupni vrednostni sistem skupine,

- dajejo socialno podporo tistim posameznikom v skupini, ki delujejo v skladu s skupnim vrednostnim sistemom,

- sankcionirajo tiste posameznike, ki ne delujejo v skladu s skupnim vrednostnim sistemom (včasih se mora posameznik odločati med lastnimi stališči in članstvom v skupini),

- izbirajo in cenzurirajo informacije, ki naj bi prišle do članov skupine; tiste informacije, ki niso v skladu z vrednostnim sistemom skupine, praviloma ne pridejo do članov skupine.

Posebno pomembno vlogo pri oblikovanju stališč imajo primarne skupine (družina, vrstniške skupine). Če obstajajo tudi referenčne skupine (skupine, katerih vrednostni sistem posameznik najbolj sprejema in se $\mathrm{z}$ njimi najbolj identificira), je njihov vpliv že posebno velik. Raziskave kažejo, da se posamezniki lahko identificirajo tudi $\mathrm{z}$ vrednostnim sistemom skupine, ki ji v resnici sploh ne pripadajo, pa ji želijo pripadati.

Demokratično vodene skupine so bile v raziskavah pri tem uspešnejše kot avtokratsko vodene. Seveda je spreminjanje stališč posameznikov pod vplivom skupin odvisno od mnogih pogojev, npr. od spoznanja, da lahko osebne probleme rešijo na kolektivni način, in od pripravljenosti, da prostovoljno sodelujejo v skupinskih procesih, ki vodijo v spreminjanje stališč.

Pomembni kolektivni cilji pripeljejo do spontanega oblikovanja neformalnih skupinskih norm, načinov obnašanja in kolektivnih prepričanj. $\mathrm{Na}$ oblikovanje skupinskih prepri- čanj močno deluje tudi konkurenca med različnimi skupinami. Posamezniki z alternativnimi ali od večine odstopajočimi stališči leteh ne morejo ohraniti, če si ne najdejo dovolj stabilne in trajne referenčne skupine somišljenikov.

Skupina izredno pomembno vpliva tudi na spreminjanje stališč pri posamezniku. Ti namreč veliko prej spremenijo svoja stališča, če je odločitev za spremembo stalíšc sprejeta v skupini, kot če jo posameznik sprejme sam.

O pomenu vzgojnega okolja pri oblikovanju osebnosti govori tudi L. Kohlberg, ko poudarja pomen t. i. "just community ", pravične skupnosti. Na moralno atmosfero gleda kot na posrednika med individualnim moralnim presojanjem in moralnim vedenjem. Kot pomemben vpliv na moralno vedenje je upošteval zapletenost dinamike skupinskega odločanja in medsebojnega zavedanja norm. Moralna klima v skupini pomaga, podpira, spodbuja ... moralno delovanje.

\section{Vpliv osebnostnih lastnosti in izkušenj na oblikovanje stališč}

Za oblikovanje stališč so zelo pomembne tiste osebnostne lastnosti in poteze, ki določajo posameznikovo samopodobo in sploh odnos do sebe. Osebe, ki kažejo veliko stopnjo samozaupanja, ki gojijo pozitivno podobo o se$\mathrm{bi}$, bodo težile $\mathrm{k}$ bolj usklajeni in trdnejši strukturi stališč. Osebnosti s šibko samopodobo, z majhnim samozaupanjem razvijajo nestabilna, pogosto med seboj nekoherentna stališča.

Zelo pomemben izvor posameznikovih stališč so njegove neposredne izkušnje in znanje. Posameznikova neposredna izkušnja je najenostavnejša oblika pridobivanja in spreminjanja stališč. Posameznikove neposredne izkušnje $\mathrm{z}$ objekti stališ̌c so praviloma povezane $\mathrm{z}$ množico interpretacij in pričakovanj, s katerimi tako posameznik sam kot socialno okolje opremljata vsako izkušnjo. Načelno pa je seveda težko razmejiti vlogo »čiste izkušnje « od vloge "socialno posredovane izkušnje».

Vpliv neposredne izkušnje na oblikovanje stališč v psihologiji pojasnjujejo predvsem $\mathrm{s}$ pogojevanjem in učenjem po modelu. Če smo dalj časa izpostavljeni podobnim dražljajem oz. podobnim situacijam, potem težimo $\mathrm{k}$ 


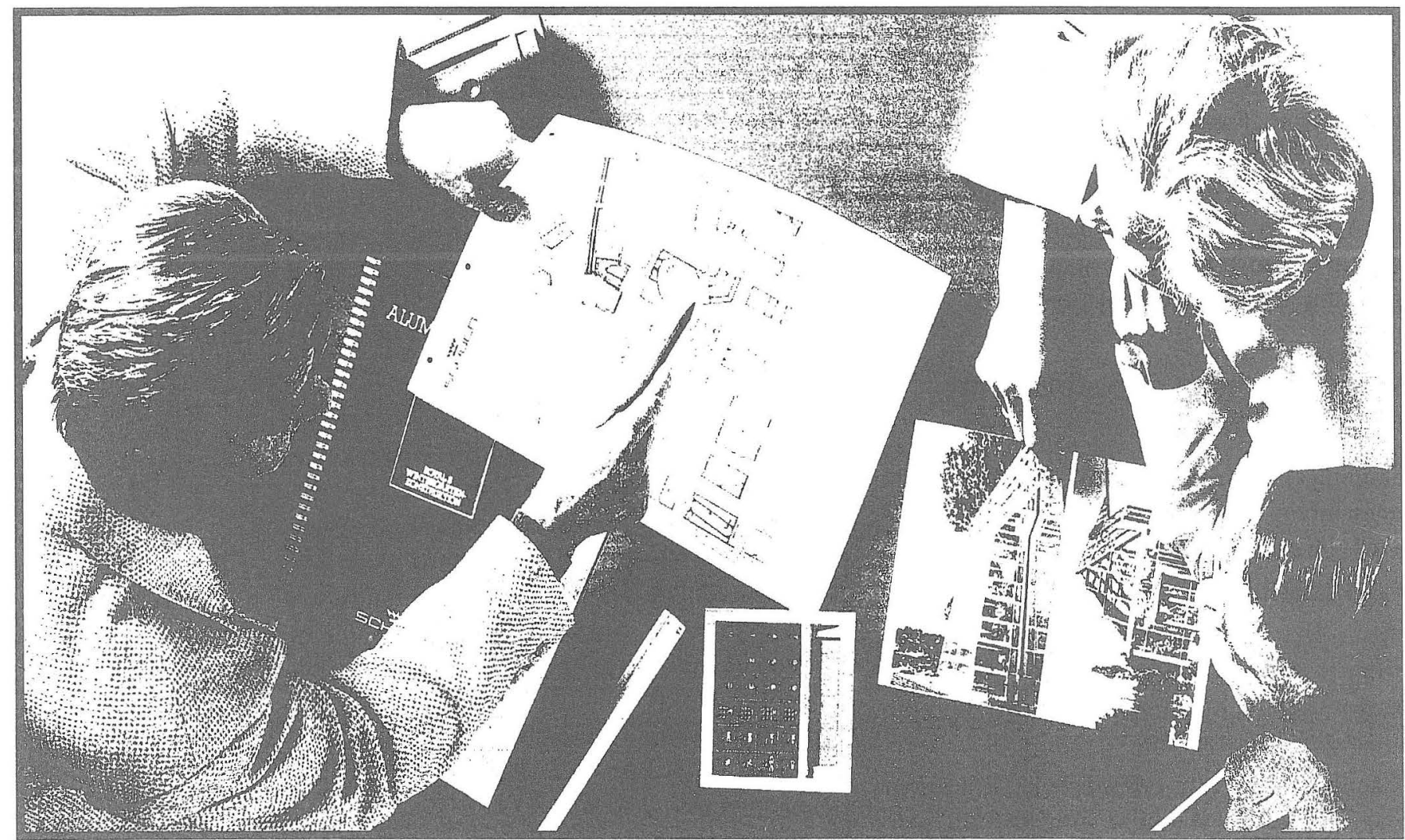

takšnim stališčem, ki so skladna $\mathrm{z}$ našimi odzivi na te dražljaje oz. situacije.

Podoben je proces učenja po modelu. Ljudje se pri oblikovanju in spreminjanju stališč pogosto ravnamo po tem, kako se vedejo tiste osebe, ki so nam vzori, so nam avtoritete ali so za nas kako drugače pomembne. Pri tem na nas delujejo tudi pozitivna poplačila ali negativne sankcije, ki jih s seboj prinaša posnemanje modelov. Če agresivno vedenje drugih ljudi v določenem socialnem okolju prinaša pozitivne učinke za tiste, ki se tako vedejo, potem bodo te osebe razvile pozitivna stališča do agresivnosti. Učenje po modelu izkoriščajo v reklamah, kjer nastopajo znane osebnosti. Občudovanje, ki ga ljudje gojijo do teh modelov, se posredno prenaša tudi na pozitivna stališča do tega, kar nam ti modeli želijo sporočiti ali sugerirati.

\section{PSIHOLOGIJA PREPRIČEVANJA}

Informacije imajo pomembno vlogo pri oblikovanju stališč v primerih, kjer ne moremo dobiti neposrednih izkušenj (zaradi časovne ali prostorske oddaljenosti dogodka ali objekta). Stališča iz druge roke (second-hand attitudes) so rezultat informacij, ki jih dobi- mo iz nekega vira. Pomemben vir informacij so množična komunikacijska sredstva.

Eden najpomembnejših virov spreminjanja stališč je verbalna komunikacija, zlasti pri prepričevanju. Elementi procesa komunikacije so: izvor sporočil - komunikator, sporočila, medij ali kanal komuniciranja, prejemnik sporočil. Ker prepričevanje sloni na komunikacijskem procesu, je potrebno pri njem upoštevati osnovne zahteve in lastnosti komunikatorjev, sporočil, medija, prejemnika in zaželenih stališč oz. vedenja, pa tudi interakcijo med temi elementi komunikacijskega procesa.

\section{Komunikator}

Značilnosti dobrega komunikatorja: zanesljivost, privlačnost in stopnja jasnosti njegovih komunikacijskih namer.

Zanesljivost vključuje resnicoljubnost, informiranost, zanesljivost njegovih virov informacij. Izkustvo majhne zanesljivosti komunikatorja traja dlje kot izkustvo velike zanesljivosti. Bolj zanesljivo delujejo tisti komunikatorji, ki že na začetku poudarijo, da nimajo namena prepričevati prejemnikov temveč zgolj predstaviti svoje mnenje ali dejstva.

Privlačnost komunikatorja je posebno po- 
membna v vizualnih medijih. Prejemniki sporočil se želijo identificirati s privlačno osebo, zato so pripravljeni sprejemati njena stališča. Poleg fizične privlačnosti je pomembna tudi medosebna privlačnost. Ljudje, ki so nam podobni, s svojim prepričevanjem bolj delujejo na nas kot osebe, ki nam niso podobne.

Izražanje namer komunikatorja: prepričevanje večinoma ni dobro, če komunikator preveč očitno izda svoje namere (da skuša pregovoriti poslušalce, gledalce $\mathrm{k}$ sprejetju določenega stališča). S tem izzove pri poslušalcih občutek, da jih ima za lahkoverne.

Socialna moč komunikatorja: gre za sposobnost komunikatorja, da nagradi ali kaznuje poslušalce. Komunikatorji $\mathrm{z}$ večjo socialno močjo so seveda vplivnejši kot tisti, ki takšne moči nimajo. Vendar pa so učinki prepričevanja, ki izhajajo iz socialne moči, običajno kratkotrajni, prejemniki se lahko nameram komunikatorja prilagodijo le navzven, to pa ne vodi v resnično spremembo stališč.

Speči učinek: gre za velikokrat opaženo težnjo, da je neko sporočilo vplivno šele pozneje, ne pa neposredno po njegovem sprejemu. Lahko se zgodi, da s časom njegov vpliv vedno bolj narašča. Običajno je to takrat, ko na začetku prejemniki ne razlikujejo komunikatorja od vsebine sporočil in je komunikator neprivlačen. $S$ časom pozabimo na neustreznost komunikatorja in se bolj usmerimo na vsebino sporočil.

\section{Sporočilo}

Gre za vprašanje enostranosti ali dvostranosti sporočil ter za izzivanje strahu pri poslušalcih. Pri enostranosti ali dvostranosti sporočil se sprašujemo, ali komunikator posreduje samo argumente $\mathrm{v}$ prid stališču ali posreduje argumente za ali proti nekemu stališču. Bolj ko je neko stališče podano realistično, stvarno in večstransko argumentirano, trajneje se utrdi v zavesti poslušalcev, če ga ti seveda sprejmejo. Vendar pa je to odvisno tudi od osebnostnih lastnosti poslušalcev, njihove izobrazbe, inteligentnosti, dominantnosti oz. submisivnosti itd. Bolj izobraženi poslušalci raje sprejemajo dvostransko informacijo in se na podlagi dobljenih informacij sami odločajo o vseh plateh nekega pojava. Manj izobraženi pa bolj zapadejo pod vpliv enostranskih informacij.
Učinek izzivanja strahu pri poslušalcih je močno sredstvo prepričevanja. Toda strah deluje tudi kot bumerang in je opozorilo manj učinkovito, kot bi bilo brez zastraševanja. To se zgodi npr. tedaj, ko imajo ljudje občutek, da se ne morejo izogniti ali da se zelo težko izognejo grozeči nevarnosti. Tedaj se zatečejo $\mathrm{k}$ obrambnemu mehanizmu izogibanja sporočilu ali zmanjševanja njegove sporočilne vrednosti.

\section{Prejemniki sporočil}

Prejemniki selektivno izbirajo informacije glede na težnjo po ravnotežju, po izogibanju napadov nanje in seveda glede na njihove osebnostne značilnosti. Ljudje običajno želijo doseči strinjanje $\mathrm{z}$ drugimi, torej so pripravljeni na soglasje $\mathrm{z}$ drugimi, npr. s komunikatorjem. Hkrati pa je močna tudi težnja ljudi, da se "branijo « pred argumenti komunikatorja. Velikokrat se namreč strinjajo $s$ povedanim preprosto zato, ker ne poznajo načina, kako bi se "obranili« pred
Raznovrstnost informacij ima veliko vlogo pri oblikovanju stališč. "napadom komunikatorja «.

Med osebnimi lastnostmi, ki močno pospešujejo ali zavirajo sprejemanje stališč komunikatorja, je najpomembnejše samospoštovanje prejemnikov sporočil. Ljudje $\mathrm{z}$ majhnim samospoštovanjem postanejo hitro odvisni od drugih oseb, hitro sprejmejo stališča drugih in prav tako hitro podvomijo o lastnih.

Močan izvor sprejemanja stališč in pripravljenosti na njihovo spremembo so naša stališča do sebe, naše samozaznavanje, samovrednotenje. Včasih nas prav težnja po jasni samozaznavi privede do tega, da sledimo mnenjem in stališčem drugih ljudi: ko imamo zmedene občutke ali čustva, ko nismo prepričani o tem, kar čutimo. V teh primerih se velikokrat brez pomislekov opremo na stališča drugih ljudi, v upanju, da nam bodo razjasnila lastno stanje.

\section{INTERAKCIIA MED ELEMENTI KOMUNIKACIJSKEGA PROCESA}

Vpliv prepričevanja je pogosto $\mathrm{v}$ nasprotju $\mathrm{s}$ predstavo o ljudeh kot racionalnih bitjih, saj želijo posamezniki velikokrat spremeniti svoja stališča že zato, ker je tisti, ki jih prepriču- 


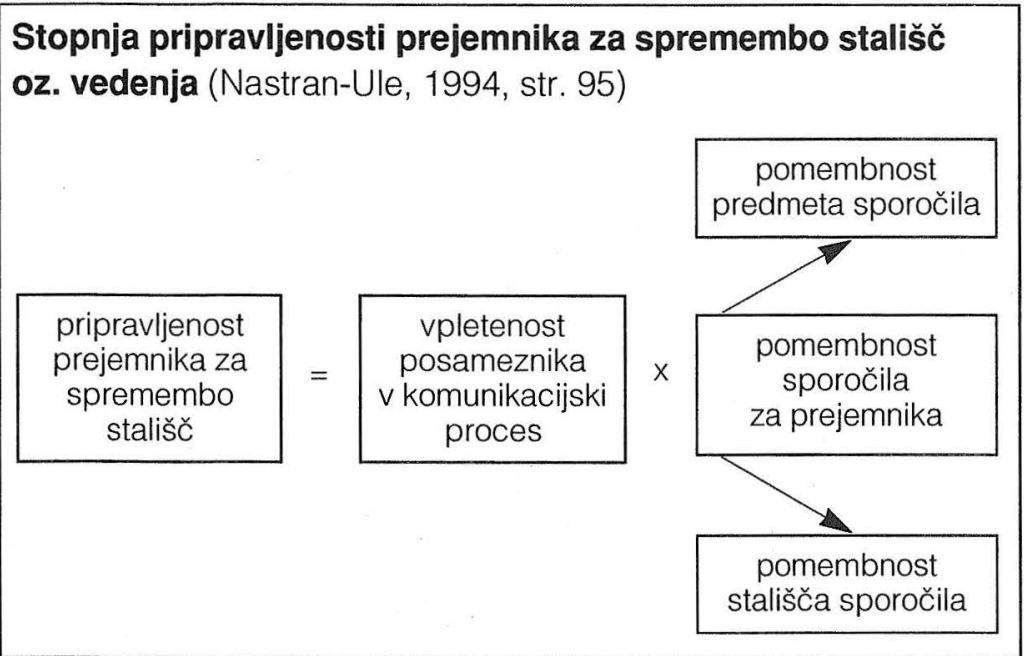

je, simpatična oseba ali jim je podoben, ali zato, ker se želijo s tem približati višjemu socialnemu položaju, ali preprosto zato, ker se želijo strinjati.

To težnjo človeka kot racionalnega bitja $\mathrm{v}$ psihologiji in v vsakdanjem življenju razlagata dve smeri: centralna in periferna.

Po razlagi centralne smeri ljudje aktivno razmišljamo o stvareh, o katerih skušamo izoblikovati stališča. $\mathrm{V}$ tem primeru je stališče rezultat racionalnega premisleka.

Periferna smer pa je zlasti v vsakdanjem življenju bolj pogosta in pomeni nereflektirano reakcijo: ljudje spreminjamo stališča že zato, ker nam je enostavnejše spremeniti stališče kot pa se s premislekom prebiti do lastnega stališča. Precej raziskav o spreminjanju stališč zajema ravno ta način spreminjanja stališč.

Katero smer bo izbral posameznik, je zelo odvisno od tega, ali se je pripravljen ukvarja- ti s problemom ali ne, oz. kako pomemben se mu zdi problem (predmet stališč). Drugi pomemben razlog izbire smeri je število informacij, argumentov, ki nam jih ponuja komunikator. Ko ima nekdo že izoblikovano stališče, bo toliko bolj spremenil stališče v skladu z namero komunikatorja, kolikor več dodatnih informacij mu bo ta ponudil. Vendar to velja samo do nekega praga informacij, ko nove informacije ne morejo več bistveno spremeniti pridobljenega stališča. To se zgodi, ko si je posameznik že izoblikoval stališče.

Pomemben izvor informacij-je tudi spomin. Če imamo do nečesa negativen odnos, potem bomo tudi iz spomina potegnili same negativne dogodke, izkušnje, misli o tem. Enako velja za pozitiven odnos. Hovland je ugotovi!, da posameznik selektivno, pristransko bere $\mathrm{v}$ svojem spominu in tudi pristransko izbira argumente za svojo pozicijo.

McGuire je predlagal dvofaktorski model spreminjanja stališč pod vplivom prepričevanja, ki vsebuje pet stopenj: pozornost, razumevanje vsebine sporočila, sprejemanje argumentov in spreminjanje stališč, trdnost spremenjenih stališč in vedenje, ki ustreza spremenjenemu stališču. Poglavitna dela tega procesa sta vzbujanje pozornosti in razumevanje sporočila na eni strani (recepcija sporočila) ter drugi deli tega procesa na drugi strani (učinek sporočila na spreminjanje stališč). To sta dva osnovna faktorja prepričevanja.

Vsak prejemnik mora po tem modelu skozi vse stopnje procesa prepričevanja; vsaka naslednja stopnja sledi šele, ko je uspešno končana predhodna.

\section{McGuirov dvofaktorski model spreminjanja stališč pod vplivom prepričevanja}

(Nastran-Ule, 1994, str. 95)

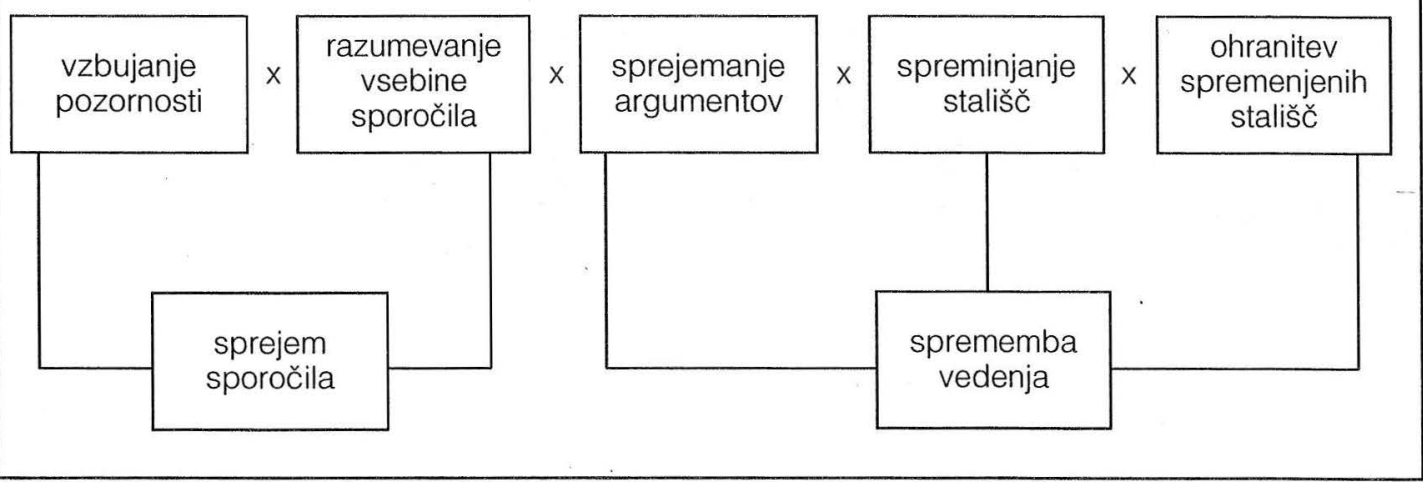




\section{VPLIV SPREMEMB V OBNAŠANJU NA STALIŠČA}

Posamezniki, skupine in institucije uporabljajo različne nagrade in/ali prepovedi, $s$ katerimi skušajo vplivati na to, da bi se drugi ljudje obnašali na zaželen način. Hkrati želijo vplivati tudi na to, da bi ljudje imeli ustrezna pozitivna stališča do svojega obnašanja. Zato je sprememba obnašanja pomemben izvor spreminjanja stališč.

Povezanost obnašanja in stališč pojasnuje novejša teorija Fishbeina in Ajzena, ki sta predpostavljala, da ljudje primarno delujejo na osnovi svojih namer, ciljev. Na namere pa močno vplivajo stališča in socialni pritiski. Povezanost stališča in obnašanja je odvisna še od pričakovanja rezultata dejanja in od vrednosti rezultata. Socialni pritisk pa je sestavljen iz prepričanj o tem, kaj morajo ljudje storiti in česa ne smejo storiti - ta prepričanja temeljijo na normativnih pričakovanjih.

\section{FISHBEINOV MODEL SPREMINIANIA VEDENIA IN STALIŠČ}

Fishbein in Ajzen sta oblikovala enega najbolje zgrajenih kognitivnih psiholoških modelov za spreminjanje vedenja. (Nastran-Ule, 1994)

Osnovni dejavnik, ki povzroči spreminjanje vedenja ali stališč, je posameznikova namera. Namera pa je odvisna od stališč posameznika do spremembe vedenja ali stališč in od norm, ki jim sledi ali jih upošteva. Vsi drugi možni dejavniki sprememb vedenja in prepričanj se vključujejo posredno, tako da dodatno preoblikujejo posameznikova stališča ali sprejete norme (druga stališča ali prepričanja, ocene možnih posledic dejanj, prepričanja o tem, kaj pričakujejo člani referenčnih skupin, poslušnost avtoritetam, institucijam, razni drugi zunanji dejavniki, kot so spol, socialni status posameznika, splošna stališča o institucijah ali ljudeh, osebnostne poteze).

Pri vplivu nagrad ali prepovedi na spremembo obnašanja in prek te na spremembo stališč moramo upoštevati predvsem razmerja med pričakovanimi rezultati obnašanja in socialnimi pritiski. V središču pozornosti je torej vplivnost novih stališč na vedenje: kakšne ve-

Ljudje tex̌imo $k$ temu, da opravičujemo to, kar poénemo, kot dobro in pravilno. Ne le da branimo svoja staliséca s svojimi dejanj, temveć tudi s svojimi stališcé branimo svoja dejanja. Uéinek obnaSanja na staliséa s pridom uporabljajo razne psihoterapije, Žal pa tudi tehnike spreobračanja in >pranja možganov $<$.

denjske učinke imajo stališča, ki jih moramo sprejeti, če hočemo doseči neko nagrado ali se izogniti kazni. Pomembno vprašanje pri tem je, ali bo vedenje, ki ga sproži sprememba stališča, v skladu z že obstoječimi stališči.

Različni teoretski pristopi na različne načine pojasnjujejo ugotovitve o vplivu sprememb v obnašanju na spremembo stališč. Teorije se med seboj dopolnjujejo. Vsaka od njih izpo-

\section{Fishbeinov model predvidevanja obnašanja posameznika iz poznavanja njegovih stališč}

(Nastran-Ule, 1994, str. 97)

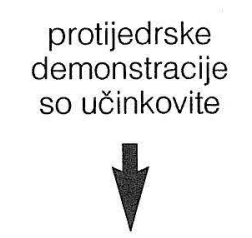

pričakovanje izida

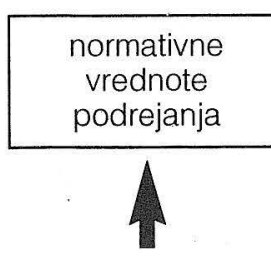

prijatelji gredo na demonstracije ustavitev širjenja jedrske energije je pomembna zame

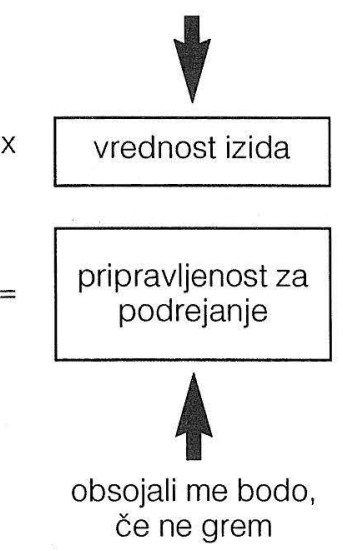

verjamem v protijedrske demonstracije

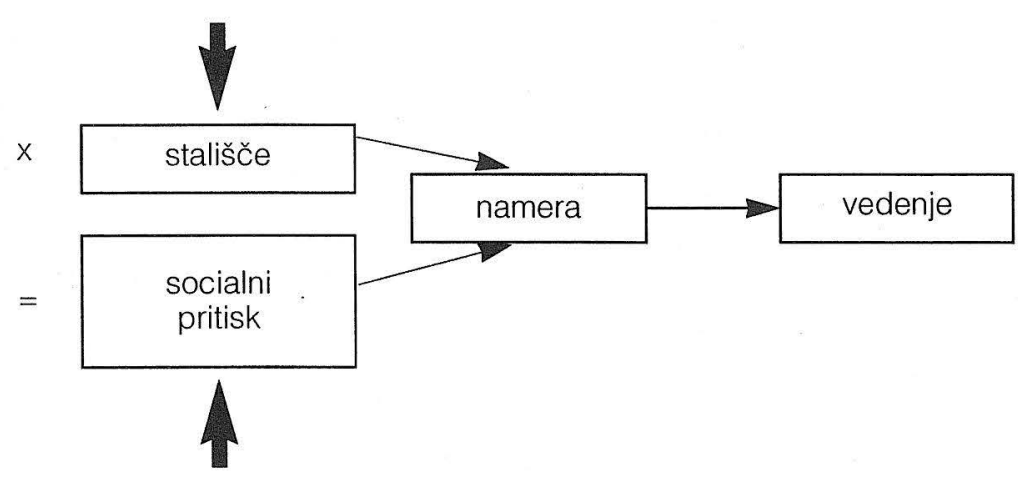

to so pomembni razlogi, da grem 


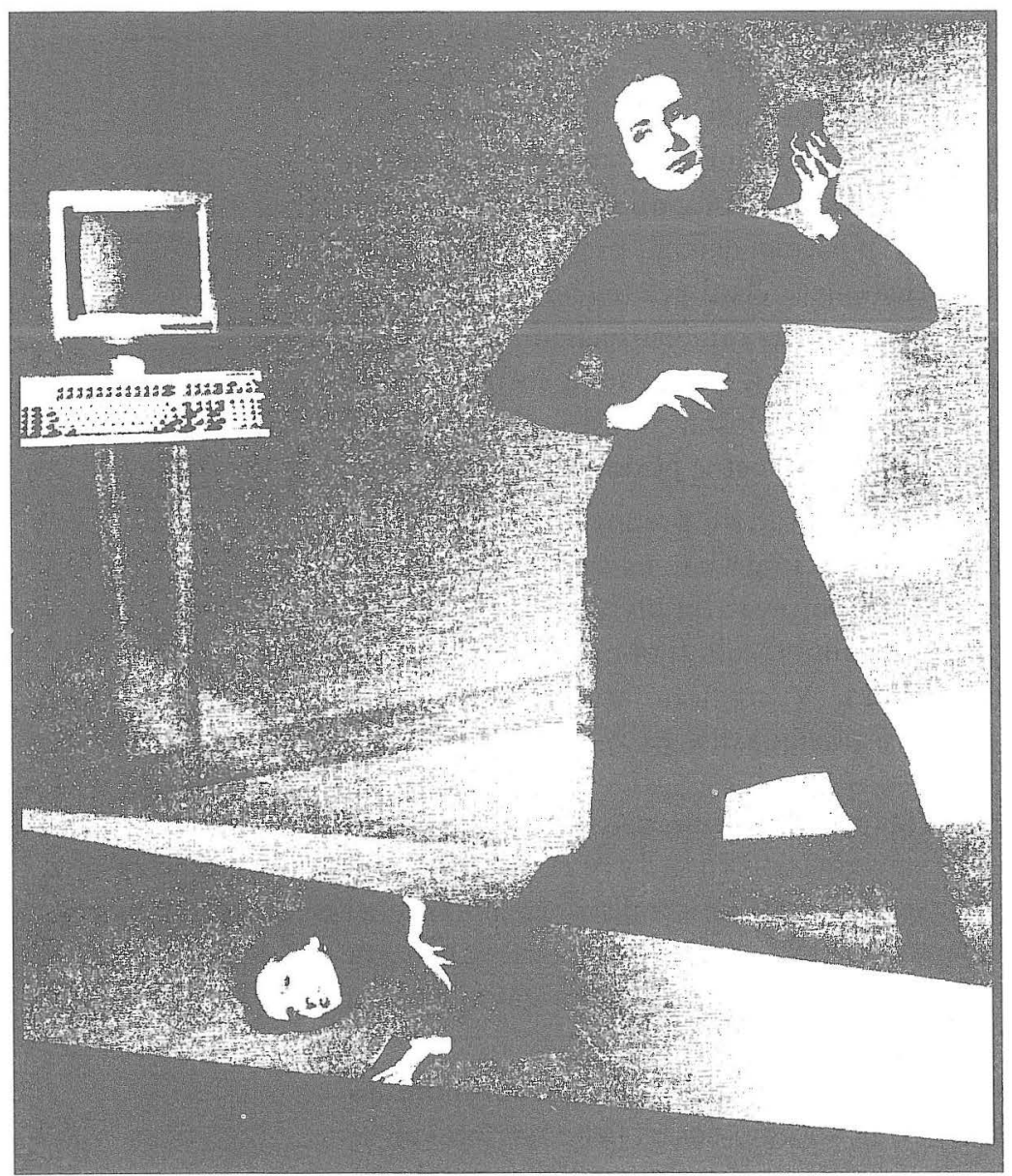

stavlja drug vidik, drug možen dejavnik $\mathrm{v}$ zvezi s spreminjanjem stališč zaradi spremenjenega obnašanja. Kateri vidik oz. kateri dejavnik bo prevladal v konkretnih okoliščinah, je odvisno od teh okoliščin in od osebnostnih lastnosti posameznikov. Nekdo je bolj občutljiv na kognitivno disonanco, drugi raje podlega stališčem drugih ljudi, tretji rad ustvarja vtis konsistentnega obnašanja ... Zato tudi ni mogoče enostavno odgovoriti, kateri dejavnik privede ljudi do spreminjanja stališč ali do spreminjanja obnašanja.

Katera sredstva in dejavniki $v$ vsakdanjem življenju najmočneje učinkujejo na spreminjanje obnašanja in stališč ljudi? Katere ukrepe je treba sprejeti, da bi ljudi odvadili škodljivih - navad (pretirano pitje, vožnja brez varnostnega pasu), kako motivirati ljudi za sprejem novih navad in potreb (vgradnja katalizatorja $\mathrm{v}$ avtomobil)? Ali naj institucije $\mathrm{v}$ teh primerih posežejo po boljših in dostopnejših informacijah ali po zakonskih sankcijah ali po nagradah?

Primeri uvajanja uporabe varnostnih pasov v prejšnje akcije množične propagande in informiranja o prednosti uporabe varnostnih pasov so bile namreč neuspešne. Preverjanje stališč voznikov - pred uvedbo kazenskih sankcij in po njej - pa je pokazalo, da se je po uvedbi sankcij močno povečal odstotek voznikov, ki so imeli do uporabe varnostnih pasov pozitivno stališče.

Ta primer govori v prid neposrednega vplivanja na spremembo obnašanja in pa o neučinkovitosti posrednega vplivanja $\mathrm{z}$ informiranjem. Res pa je, da so učinki takšnega pogojevanja sicer takojšnji in množični, vendar tudi zelo kratkotrajni in površinski. Če odpade grožnja z negativnimi sankcijami, se ljudje zelo hitro vrnejo $k$ starim načinom obnašanja in k starim stališčem. Enako se zgodi tudi tedaj, ko ni mogoč učinkovit in stalen nadzor nad obnašanjem ljudi: omejitve hitrosti vožnje postajajo zelo hitro neučinkovite, če jih ne spremlja redna radarska kontrola na cestah.

Teh slabosti pri posrednih vplivih s pregovarjanjem in informiranjem ne srečamo. Tu so sicer spremembe obnašanja zelo počasne, nemnožične, vendar so tudi trajne, ko se enkrat vzpostavijo. Ljudje sprejmejo te spremembe na osnovi lastnega premisleka in razlogov. Torej so spremembe stališč, ki se zgodijo prek "centralne smeri«, trajnejše kot tiste, ki se zgodijo na način »periferne smeri«. Prve so bolj odvisne od posameznika, so počasnejše in nemnožične, druge pa so kolektivne in množične, hitrejše ter manj odvisne od posameznika.

Ko je v družbi potrebno na hitro uvesti relativno površinske spremembe $\mathrm{v}$ obnašanju in stališčih, je gotovo primernejše zanašanje na neposredne eksterne vplive. Ko pa gre za globlje in dolgoročnejše spremembe, je primernejša uporaba posrednih in internih vplivov. Ni pa mogoče hkrati doseči obojega: hitre in učinkovite spremembe obnašanja/zavesti na osnovi zunanjega pritiska institucij oblasti ter dolgoročne spremembe obnašanja/zavesti ljudi, zasnovane na notranje sprejetih stališčih. Kolikor bolj se povečuje pritisk institucij, ideologije na ljudi, toliko bolj se ljudje le na zunaj prilagajajo tem pritiskom. (Nastran-Ule, 1994)

Vid Pečjak (1994) opredeljuje nekaj značilnih razlik med propagando, reklamo ter vzgojo in izobraževanjem: 


\begin{tabular}{ll}
$\begin{array}{ll}\text { Propaganda, reklama, indoktrinacija, } \\
\text { pranje možganov }\end{array}$ & Vzgoja, izobraževanje, prosvetljevanje \\
\hline \begin{tabular}{ll} 
obllkuje in sprosća reflekse in navade \\
\hline vedenje je nezavedno in avtomatično
\end{tabular} & spodbuja resevanje problemov \\
\hline reagiranje na signale & vedenje je zavestno in avtonomno \\
\hline bistveno je ponavljanje & odločanje na podlagi znanja \\
\hline potrebne so zunanje nagrade in kazni & potrebno je notranje nagrajevanje \\
\hline oblikovanje in spreminjanje struktur & oblikovanje in spreminjanje struktur po volit \\
\hline mimo volje posameznika & posameznika \\
\hline sprejemanje ponudbe & izbiranje ned alternativami \\
\hline
\end{tabular}

Pečjakove ugotovitve samo potrjujejo pomembnost izobraževanja in vzgoje pri spreminjanju stališč in delovanju $\mathrm{v}$ skladu $\mathrm{s}$ temi stališči. Ob tem pa se je pomembno zavedati kompleksnosti in sestavljenosti stališč iz kognitivne, emotivne in konativne - aktivnostne komponente.

\section{SIKLEP}

Sodobni človek se sooča $\mathrm{z}$ neprestanim iskanjem, vedno novim odkrivanjem in preiskovanjem svojih prepričanj, stališč, znanja. Pri tem naj mu v procesu osebnostnega zorenja, oblikovanja $\mathrm{v}$ osebo, ki bo temeljila na vrednoti »biti «, ne le »imeti «, pomaga izobraževanje. Izobraževanje je razvijanje osebnosti, proces osvobajanja vseh sposobnosti osebnosti v soočanju z raznolikostjo izkustev, s katerimi se srečuje. (Lengrand, 1976)

Proces oblikovanja in spreminjanja stališč ter celotnega moralnega zorenja pomeni stalno iskanje in razmišljanje, v zavedanju, da nikoli nismo popolni, a smo na poti $\mathrm{k}$ popolnosti. Zato se ne želimo nikoli ustaviti, ker to hkrati pomeni konec našega osebnostnega razvoja in njegovo nazadovanje. Vsak posameznik je enkratna in neponovljiva oseba, zato je tudi proces zorenja in s tem povezane vloge izobraževanja pri vsakem posamezniku nekaj enkratnega. Da bi dan za dnem bolj postajal to, kar je. Oseba.

\section{LITERATURA}

L'Abate, L. (1993): A theory of personality development. John Wiley \& Sons, Inc., New York.

Kiesler, A. C. (1969): Attitude Change, A Critical Analysis of Theoretical Approaches. John Wiley \& Sons, Inc., New York.

Kitagawa, H. (1986): The Ethical Domain. V: Lengrand, P.: Areas of Learning Basic to Lifelong Education. Unesco institute for education Hamburg, FRG, Pergamon Press, Oxford.

Kohlberg, L. (1974): Education, Moral Development and Faith. V: Journal of Moral Education, vol. 4.

Lengrand, P. (1976): Uvod u permanentno obrazovanje. Beogradski izdavačko-grafički zavod, Beograd.

Musek, J. (1993a): Osebnost in vrednote. Educy, Ljubljana.

Musek, J. (1993b): Psihologija. Človek in družbeno okolje. Educy, Ljubljana.

Musek, J. (1993c): Znanstvena podoba osebnosti. Educy, Ljubljana.

Nastran-Ule, M. (1994): Temelji socialne psihologije. Znanstveno in publicistično središče, Ljubljana.

Pečjak, V. (1994): Psihologija množice. Samozaložba, Ljubljana.

Psihodiagnostika osebnosti II, uredila T. Lamovec (1994). Znanstveni inštitut Filozofske fakultete, Ljubljana.

Zupančič, M. (1989): Temeljna psihološka spoznanja o moralnem razvoju. Anthropos, št. 1-2 in 3-4, Ljubljana

Zvonarević, M. (1978): Socijalna psihologija. Školska knjiga, Zagreb. 